\title{
Soft Tissue Rheumatic Disorders
}

\author{
Roaa Mahroos and Hani Almoallim
}

\subsection{Introduction}

Soft tissue disorders are common focal pathological syndromes affecting soft tissue structures like tendons, ligaments, bursa, fascia, and the site of insertions of these structures to bones (enthesis). They are commonly encountered disorders in daily clinical practice particularly in outpatient settings. A systemic disease does not always accompany them; , however, they can be associated with spondyloarthritis. They are most likely caused by overuse, repetitive trauma, and occupational history. This chapter will present in a simplified approach different types of bursitis, tendinitis, enthesitis, and fasciitis encountered in clinical practice. The emphasis will be placed on diagnostic workup based on comprehensive history-taking skills and musculoskeletal (MSK) examination findings. Outlines of management principles will be reviewed as most of these disorders respond to conservative therapy (pain management, physiotherapy, and avoidance of aggravating movements) and it rarely needs surgical intervention. There are other soft tissue disorders discussed in "Diabetes and Rheumatology" Chap. 21. Detailed techniques

R. Mahroos $(\bowtie)$

Doctor Samir Abbas Hospital (DSAH),

Jeddah, Saudi Arabia

e-mail: roaa.mahroos@dsah.sa

H. Almoallim

Medical College, Umm Al-Qura University (UQU),

Makkah, Saudi Arabia

e-mail: hmmoallim@uqu.edu.sa

(C) The Author(s) 2021

H. Almoallim, M. Cheikh (eds.), Skills in Rheumatology, https://doi.org/10.1007/978-981-15-8323-0_22 of MSK examination of several of these disorders are discussed in Chap. 2.

\subsubsection{Learning Objectives}

By the end of this chapter, you should be able to:

- Discuss the anatomy and classification of common soft tissue disorders (bursa, ligaments, tendons, and fascia) that cause localized pain syndromes.

- Describe the clinical presentation of the most common types of soft tissue disorders.

- Construct a diagnostic approach for different types of soft tissue disorders.

- Outline management principles of these disorders.

\subsubsection{Classification of Soft Tissue Disorders}

A selective group of soft tissue disorders will be reviewed in this chapter based on the following classification (Fig. 22.1). It is based on the site of involvement of these structures. It is important to consider soft tissue disorders in the differential diagnosis of regional pain syndromes. 


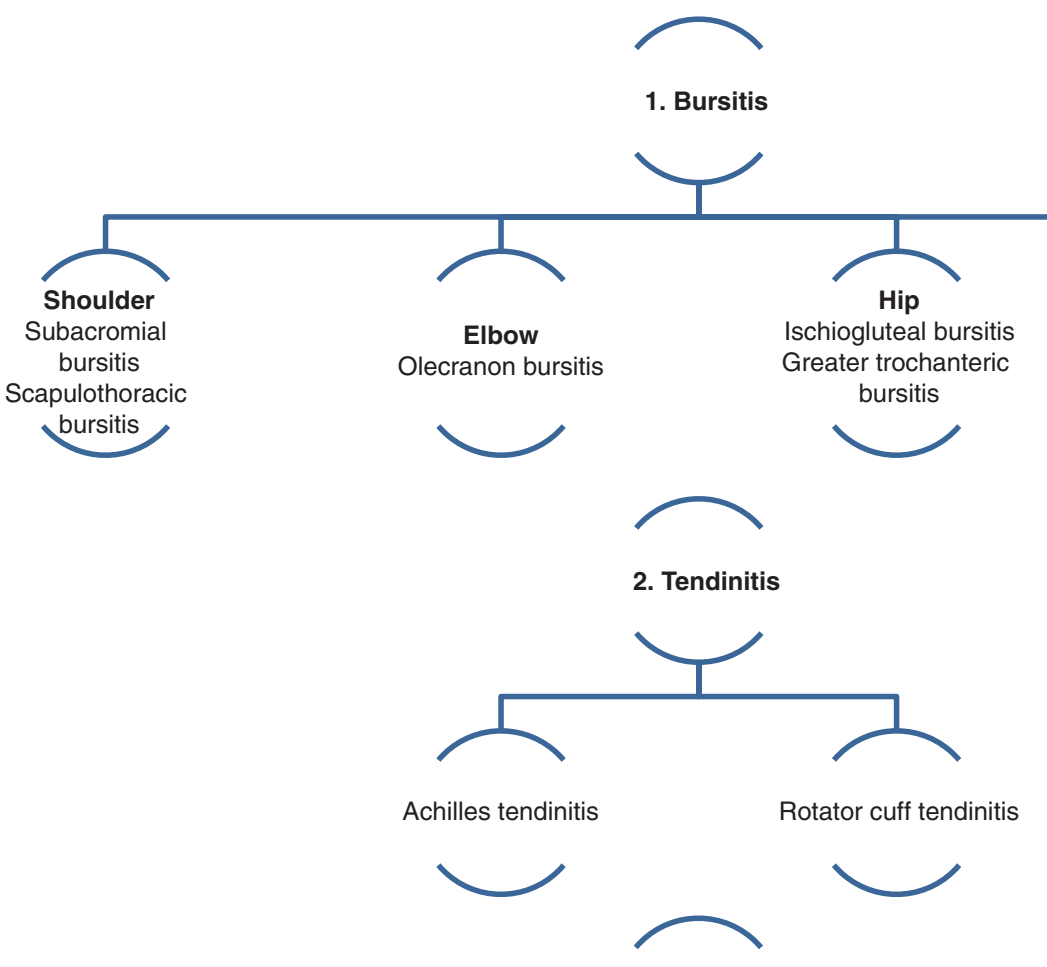

\section{Enthesitis}
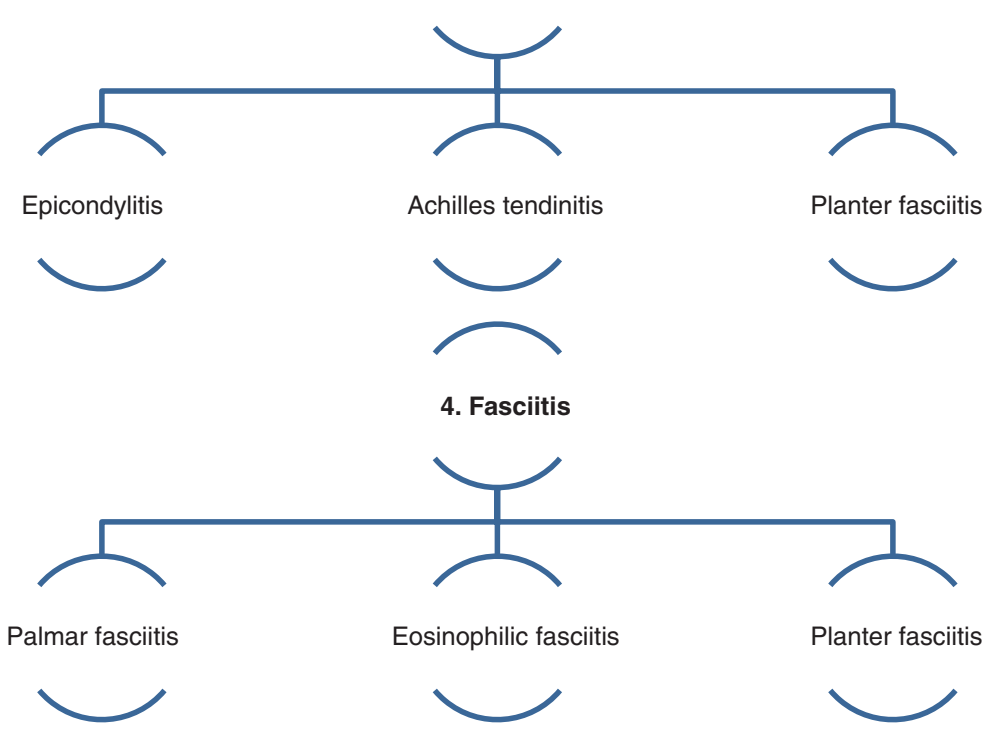

Fig. 22.1 Classification of soft tissue disease in rheumatology 


\subsubsection{Bursitis}

It is important to realize the anatomical definition of a bursa in order to recognize the clinical presentation of bursitis. A bursa is simply the sac structure that is formed of two layers filled with synovial fluid that protects other structure underneath it from injuries caused by pressure. This sac acts as cushions. Bursitis is simply inflammation of this sac.

The most common sites are shoulder (subdeltoid, olecranon), hip (ischial tuberosity, trochanteric), knee (prepatellar bursa), and foot (retrocalcaneal) [1-9]. Table 22.1 represents a comprehensive a general review of the clinical presentation, investigation, and treatment of bursitis. Table 22.2 represents a review of specific types of bursitis.

\subsubsection{Tendinitis}

A tendon is a thick fibrous cord that attaches muscle to bone. Inflammation in the tendon is called tendinitis. The most common sites for ten-

Table 22.1 Review of the Bursitis history, physical examination, investigation, and treatment

\begin{tabular}{|c|c|}
\hline History & $\begin{array}{l}\text { - Pain: Assess duration, site, localization, increases with movement, relation to position, } \\
\text { interferes with activity, recurrence, other joint pains, stiffness, and functional disability (at } \\
\text { home, work, and leisure activities) } \\
\text { - Occupation: Repetitive movement disorder that increase pressure in the joint and its } \\
\text { surrounding soft tissue structures. For example, overhead lifting, pushing up elbows when } \\
\text { arising from bed, carrying heavy objects, prolong sitting on hard surface, and repeated } \\
\text { kneeling } \\
\text { - History of trauma: Systemic review for evidence of a systemic disease (see Chap. 1) like } \\
\text { rheumatoid arthritis (RA), crystal-induced arthritis (gout, pseudogout) and uremia } \\
\text { - History suggestive of infection: Fever, (infective endocarditis, cellulitis), skin abrasions in } \\
\text { superficial bursae (olecranon and prepatellar bursa) wounds, and diabetic, alcoholic [5-7] } \\
\text { and immunosuppressed patients are at increased risk of septic bursitis [8,9] } \\
\text { - Obesity }\end{array}$ \\
\hline $\begin{array}{l}\text { Physical } \\
\text { examination }\end{array}$ & $\begin{array}{l}\text { - Swelling: Mainly superficial } \\
\text { - Tenderness: With active range of motion (ROM) testing } \\
\text { - Reduced active ROM: With less or no pain with passive ROM } \\
\text { - Local tenderness: With palpation over the bursa } \\
\text { - In septic bursitis: Fever, swelling, redness, tenderness, and hotness [10] }\end{array}$ \\
\hline Investigations & $\begin{array}{l}\text { 1. If history and physical examination suggest septic bursitis } \\
\text { a. CBC, blood culture, and glucose } \\
\text { 2. Bursa fluid aspiration: [11] } \\
\text { Deep bursa use US or MRI guided aspiration, and fluid for } \\
\text { a. Cell count: } \\
\text { Normal WBC: less than } 200 / \mathrm{L} \text {. } \\
\text { Noninflammatory WBC: } 200-2000 / \mathrm{L} \text {. } \\
\text { Inflammatory WBC: } 2000-100,000 / \mathrm{L} \text {. } \\
\text { Septic bursitis WBC: may be exceeding 100, 000/ L } \\
\text { b. Gram stain and culture in liquid media: [10] It is } \\
\text { Positive in two-thirds of patients with septic bursitis [8]. } \\
\text { The most common organisms: Staphylococcus aureus In about } 80 \% \text { of cases, [8, } 9,12 \text {, } \\
\text { 13] streptococci beta-hemolytic strain, rare coagulase negative staph, Enterococcus, E. } \\
\text { coli, and Brucella, or TB in subacute and chronic endemic areas } \\
\text { c. Crystal analysis utilizing compensated polarized microscopy } \\
\text { d. Bursa fluid glucose: Serum glucose ratio of < } 50 \% \text { [14] } \\
\text { 3. Imaging typically not helpful in acute superficial bursitis: } \\
\text { a. Plain X-ray: When there is history of trauma or foreign body and to exclude crystal- } \\
\text { induced arthritis particularly chondrocalcinosis } \\
\text { b. CT or MRI: Particularly in septic bursitis to confirm the presence of abscesses or fluid } \\
\text { collection }\end{array}$ \\
\hline
\end{tabular}


Table 22.1 (continued)

\begin{tabular}{|c|c|}
\hline Treatment & $\begin{array}{l}\text { 1. Patient education } \\
\text { a. Avoid aggravating factors that increase joints pressure } \\
\text { b. Joint protection program using cushion and pads } \\
\text { c. Rest joint position to decrease pressure } \\
\text { d. Weight reduction } \\
\text { 2. Pain control and decrease inflammation: } \\
\text { a. NSAIDs (see Chap. } 4 \text { ): } \\
\text { selective cyclooxygenase } 2 \text { inhibitor (celecoxib } 200 \mathrm{mg} \text { twice daily) or nonselective } \\
\text { (naproxen } 500 \text { mg twice daily for few days in acute bursitis) } \\
\text { b. Local glucocorticoid injection: } \\
\text { after ruling out septic bursitis with negative culture } \\
\text { there is limited data on efficacy and safety;, in general it is more effective than NSAID in } \\
\text { speeding recovery, relieving pain, and preventing recurrence of olecranon and } \\
\text { subacromial bursitis [ } 7 \text { ] } \\
\text { long-acting glucocorticoid (methylprednisolone } 40 \text { mg for large bursa, subacromial or } \\
\text { trochanteric, and } 10 \text { mg for small bursa, anserine or Ischia) mixed with equal amount of } \\
1 \% \text { lidocaine } \\
\text { injection should not be repeated for } 6-8 \text { weeks } \\
\text { c. Apply ice for } 20 \text { min } 6-4 \text { times per day } \\
\text { d. Heat not more than } 20 \text { min } \\
\text { Septic bursitis: } \\
\text { treatment in immunocompetent or nondiabetic patients: } \\
\text { Oral antibiotic (dicloxacillin or second-generation cephalosporin or clindamycin) for } 10 \\
\text { days if there is improvement } \\
\text { frequent aspiration of the bursa and continue antibiotic for } 5 \text { days post sterilization } \\
\text { in severe cases and in immunosuppressed patients: } \\
\text { IV broad-spectrum antibiotic to cover pseudomonal plus anti-methicillin-resistant } S \text {. } \\
\text { aureus (MRSA) (vancomycin) for } 2-3 \text { weeks, till the culture and sensitivity results are } \\
\text { available [15] } \\
\text { repeat bursa drain and debridement or open surgical drain in deep bursitis }\end{array}$ \\
\hline
\end{tabular}

Table 22.2

\begin{tabular}{|c|c|}
\hline \multicolumn{2}{|c|}{ Subacromial bursitis } \\
\hline Anatomy & $\begin{array}{l}\text { Subacromial bursa lies between acromion process and supraspinatus muscle at top of the } \\
\text { humorous } \\
\text { Bursitis results from inflammation of supraspinatus tendon }\end{array}$ \\
\hline $\begin{array}{l}\text { Action of } \\
\text { supraspinatus } \\
\text { muscle }\end{array}$ & Abduction of the shoulder \\
\hline Symptoms & $\begin{array}{l}\text { - severe pain at rest and movement of the affected shoulder } \\
\text { - prevent active movement }\end{array}$ \\
\hline Signs & $\begin{array}{l}\text { - tenderness over the bursa just below the acromion } \\
\text { - this may extend over deltoid muscle } \\
\text { - tender and possibly restricted active ROM, while passive abduction is harmless with } \\
\text { possibility of mild tenderness }\end{array}$ \\
\hline Treatment & $\begin{array}{l}\text { Pain is markedly relieved after injecting local anesthesia, immobilization, rest of the joint, and use } \\
\text { of NSAIDs } \\
\text { If not improving after } 72 \mathrm{~h} \text {, inject methylprednisolone } 40 \mathrm{mg} \text { with lidocaine }\end{array}$ \\
\hline Comment & $\begin{array}{l}\text { It is associated with: } \\
\text { - rotator cuff tear that presents with supraspinatus muscle weakness } \\
\text { - polymyalgia rheumatic when it is usually bilateral }\end{array}$ \\
\hline \multicolumn{2}{|c|}{ Scapulothoracic bursitis $[2-4]$} \\
\hline Anatomy & The bursa is located in medial angle of scapula and adjacent to second and seventh ribs \\
\hline Symptoms & $\begin{array}{l}\text { Pain and popping sensation with scapulothoracic movement } \\
\text { It increases with working overhead, pushing up, reaching up, and shoulder shrugging }\end{array}$ \\
\hline Signs & Localize tenderness and crepitus with movement \\
\hline
\end{tabular}


Table 22.2 (continued)

\begin{tabular}{l|l}
\hline Treatment & $\begin{array}{l}\text { ・ spontaneous regression in most of the patients [1] } \\
\text { • physiotherapy: Postural and scapular strengthening exercise [2] } \\
\text { ・ US heat stretching test might help } \\
\text { ・ if pain persists, glucocorticoid injections under fluoroscopy might be considered } \\
\text { • surgery might be indicated in refractory cases [3] }\end{array}$ \\
\hline Olecranon bursitis (student's elbow) [9-12]
\end{tabular}

Ischiogluteal bursitis (Weaver's bottom)

\begin{tabular}{l|l}
\hline Anatomy & The bursa is located between gluteus medius muscle and ischial tuberosity \\
\hline Symptoms & $\begin{array}{l}\text { Pain in sitting and lying position. Also, pain in lower buttock after prolonged sitting } \\
\text { On hard surfaces }\end{array}$ \\
\hline Signs & Tenderness over ischial tuberosity \\
\hline Treatment & NSAIDs, glucocorticoid injection, foam rubber cushion, and stretching with knee to chest exercise
\end{tabular}

\section{Greater trochanteric bursitis}

\begin{tabular}{|c|c|}
\hline Anatomy & $\begin{array}{l}\text { The bursa is located between the tendon of gluteus medius and posterolateral prominence of } \\
\text { greater trochanter } \\
\text { This bursitis is more common in females rather than males }\end{array}$ \\
\hline Symptoms & $\begin{array}{l}\text { Night pain, lateral hip pain, } 40 \% \text { radiate to the lateral site of the thigh, worsening if lying on } \\
\text { affected side, and patient cannot walk in severe case } \\
\text { Iliotibial band syndrome (snapping hip) and leg length discrepancy predispose patients to develop } \\
\text { trochanteric bursitis }\end{array}$ \\
\hline Signs & $\begin{array}{l}\text { - tenderness on lateral hip joint pain region over the greater trochanter } \\
\text { - hip joint resisted hip abduction may reproduce symptoms } \\
\text { - antalgic gait } \\
\text { Notes: } \\
\text { The differences between greater trochanteric bursitis and gluteus medius tendinopathy are gluteus } \\
\text { medius tendinopathy causes pain and tenderness superior to the greater trochanter, positive } \\
\text { Trendelenburg test, significant muscle weakness, and positive one-Leg mini-squat test, patient } \\
\text { cannot complete a single repetition squat on affected leg to } 60^{\circ} \\
\text { Recommended X-ray: Lateral, anteroposterior, and frog-leg views to rule out other causes } \\
\text { affecting hip joint itself }\end{array}$ \\
\hline Treatment & $\begin{array}{l}\text { Radiating radicular pains from the lower back need to be ruled out as well. } \\
\text { Heat and passive stretching exercise with hip adduction can be tried with weight reduction and } \\
\text { avoiding stairs } \\
\text { Some resistant cases may need to be injected with glucocorticoid and lidocaine } \\
\text { Spinal needles should be used in obese patients }\end{array}$ \\
\hline \multicolumn{2}{|c|}{ Prepatellar bursitis (Housemaid's knee) [1-9] } \\
\hline Anatomy & The bursa is located between the patella and the skin \\
\hline Symptoms & $\begin{array}{l}\text { Positive history of kneeling down frequently and/or history of trauma } \\
\text { Anterior knee pain that increases with flexion } \\
\text { Swelling may be observed }\end{array}$ \\
\hline Signs & $\begin{array}{l}\text { Tenderness over the patella. Swelling, hotness, and redness particularly in septic or crystal- } \\
\text { induced bursitis }\end{array}$ \\
\hline Treatment & $\begin{array}{l}\text { Rule out septic bursitis and/or crystal-induced bursitis with bursal fluid aspiration } \\
\text { Rest joint and avoid trauma. Glucocorticoid injection may be considered } \\
\text { In refractory cases refer to surgery }\end{array}$ \\
\hline
\end{tabular}


Table 22.2 (continued)

\begin{tabular}{|c|c|}
\hline \multicolumn{2}{|c|}{ Anserine bursitis (Goose's foot) } \\
\hline Anatomy & $\begin{array}{l}\text { The bursa is located medially around } 6 \mathrm{~cm} \text { below the joint line at the attachment of medial } \\
\text { collateral ligament to medial tibia } \\
\text { It is the site of insertion of three tendons: gracilis, sartorius, and semitendinosus muscles }\end{array}$ \\
\hline Symptoms & $\begin{array}{l}\text { Risk factors: Positive history of repeated knee flexion in excessive running, stair climbing. } \\
\text { More common in obese elderly females and/or with valgus knee alignment } \\
\text { Pain at night over the upper tibia around } 6 \mathrm{~cm} \text { below medial joint line } \\
\text { It is important to ask the patient to point with one finger the area of pain }\end{array}$ \\
\hline Signs & $\begin{array}{l}\text { Local tenderness over the exact anatomical location of the bursa. Rule out medial collateral } \\
\text { ligament instability (see Chap. 2) }\end{array}$ \\
\hline Treatment & $\begin{array}{l}\text { Rest. Repeated knee bending should be avoided; also avoid crossing the leg or frequent squatting positions } \\
\text { Use pillow under the knee as a relaxation technique. Ice bags may be applied. NSAIDs can be used, } \\
\text { and if there is no improvement after } 6-8 \text { weeks, local glucocorticoid injection can be considered. }\end{array}$ \\
\hline \multicolumn{2}{|c|}{ Gastrocnemius semimembranosus bursitis (Baker’s cyst) } \\
\hline Anatomy & $\begin{array}{l}\text { The bursa is located between gastrocnemius and semimembranosus muscles on the medial side } \\
\text { distal to the crease in the popliteal fossa back of the knee } \\
\text { Most common in adult from } 35-70 \text { years old, and it increases with age because the } \\
\text { communications between the knee and bursa increase [16] }\end{array}$ \\
\hline Symptoms & $\begin{array}{l}\text { Asymptomatic accidental finding during physical examination or radiological investigation } \\
\text { Posterior knee pain and stiffness that increase with activity } \\
\text { Swelling or discomfort in prolong that standing and hyperflexion }\end{array}$ \\
\hline Signs & $\begin{array}{l}\text { Swelling in posterior aspect of the knee, more marked with knee extension } \\
\text { Absence of swelling on knee flexion up to } 45^{\circ} \text { (Foucher's sign) } \\
\text { Ecchymosis below the medial malleolus (cresent's sign) in rupture baker's cyst }\end{array}$ \\
\hline Causes & $\begin{array}{l}\text { One third of causes is due to trauma. Two thirds of the causes are due to other diseases } \\
\text { (osteoarthritis, rheumatoid arthritis, septic arthritis and meniscal tear) }\end{array}$ \\
\hline Complication & Pseudothrombophlebitis, leg ischemia, compartment syndrome, nerve entrapment, and ruptured [17] \\
\hline Treatment & $\begin{array}{l}\text { Investigation by US or MRI } \\
\text { Treat underlying disease } \\
\text { If asymptomatic no treatment } \\
\text { In arthrocentesis and intra-articular corticosteroid injection result in decrease size after } 4 \text { weeks by } \\
\text { US follow-up [18] } \\
\text { Direct cyst injection if it does not communicate with the joint } \\
\text { Surgery is indicated in recurrences and lack of response to glucocorticoid injection }\end{array}$ \\
\hline
\end{tabular}

dinitis are around shoulder, elbow, and ankle joints. One of the pathophysiological mechanisms for tendinitis is micro-tears, affecting these tendons from repeated stressors like in overuse, or in traumatic situations.

In some situations where there is inflammation of the tendon sheath, the condition is called tenosynovitis. Table 22.3 represents a comprehensive, general review of the clinical presentation, investigation, and treatment of tendinitis.

Table 22.4 represents a review of rotator cuff tendinitis.

Tendinosis is a chronic proses associated with an atrophic and degenerative change of the tendon caused by recurrent tendinitis. US or MRI is required to diagnose it and to differentiate between different causes.

\subsubsection{Rotator Cuff Tendinitis and Rotator Cuff Tear}

Rotator cuff tendinitis (RCT) is a common type of tendinitis that affects the shoulder. The patient usually presents with lateral shoulder pain and limited active ROM. It is the most common cause of shoulder pain in clinical practice. A brief approach to shoulder pain is presented in Chap. 2. Table 22.4 represents a comparison between $\mathrm{RCT}$ and rotator cuff tear (RCTr) in terms of definition, diagnostic, and therapeutic interventions. 
Table 22.3 Review of the tendonitis history, examination, diagnosis, treatment, and prevention

\begin{tabular}{|c|c|}
\hline History & $\begin{array}{l}\text { - Localized pain over the tendon with active movement particularly } \\
\text { - Limited activity } \\
\text { - Occupation: overuse and/or sporting activity, usually in middle age group of patients }\end{array}$ \\
\hline Risk factors & $\begin{array}{l}\text { Intrinsic } \\
\text { - Age over } 35 \text { years and obesity } \\
\text { - Biomechanical abnormalities: Mostly located in lower limbs (pes planus [flat foot], pes cavus, } \\
\text { reduced planter dorsiflexion, pelvic inequality and kyphosis) } \\
\text { - Previous tendinitis or rupture } \\
\text { - Fluoroquinolones use [19] } \\
\text { Extrinsic } \\
\text { - Training error (sudden increase and inadequate rest) } \\
\text { - Environmental (hard gym floors, frozen turf) } \\
\text { - Poor equipment (inappropriate footwear) } \\
\text { - Poor ergonomics excessive movement }\end{array}$ \\
\hline Examination & $\begin{array}{l}\text { - Localized tendon pain } \\
\text { - Pain with tendon loading } \\
\text { - Pain with passive stretching } \\
\text { - Pain with active movement } \\
\text { - Normal ROM on passive test } \\
\text { - Muscle weakness in chronic tendinitis and tendon tear }\end{array}$ \\
\hline Diagnosis & $\begin{array}{l}\text { US and MRI: } \\
\text { - Help to diagnose partial or complete tendon tear } \\
\text { - Tendon thickness } \\
\text { - To rule out other causes particularly if patient did not improve on treatment }\end{array}$ \\
\hline Treatment & $\begin{array}{l}\text { - Avoid aggravating activity } \\
\text { - Apply ice over the tendon for } 15 \text { min } 4-6 \text { times daily } \\
\text { - NSAIDs and local glucocorticoid injection in severe cases } \\
\text { - Physiotherapy: Range of motion stretching and strengthening exercises, eccentric exercise, and } \\
\text { aerobic fitness } \\
\text { - Surgery: probably after } 6 \text { months if no improvement or acute tendon rupture }\end{array}$ \\
\hline
\end{tabular}

Table 22.4 Review of the tendonitis history, examination, diagnosis, treatment, and prevention [21, 22]

\begin{tabular}{|c|c|c|c|}
\hline \multirow[t]{2}{*}{ Anatomy } & Rotator cuff muscles & Origin on scapula & Insertion on humerus \\
\hline & $\begin{array}{l}\text { Supraspinatus } \\
\text { Subscapularis } \\
\text { Infraspinatus } \\
\text { Teres minor }\end{array}$ & $\begin{array}{l}\text { Supraspinous fossa } \\
\text { Subscapular fossa } \\
\text { Infraspinous fossa } \\
\text { Lateral border }\end{array}$ & $\begin{array}{l}\text { Insertion on humerus } \\
\text { Superior facet of greater tuberosity } \\
\text { Lesser tuberosity } \\
\text { Middle facet of greater tuberosity } \\
\text { Inferior facet of greater tuberosity }\end{array}$ \\
\hline \multirow[t]{2}{*}{ Muscle action } & Rotator cuff muscles & \multicolumn{2}{|l|}{ Mscle action } \\
\hline & $\begin{array}{l}\text { Supraspinatus } \\
\text { Subscapularis } \\
\text { Infraspinatus } \\
\text { Teres minor }\end{array}$ & \multicolumn{2}{|l|}{$\begin{array}{l}\text { Abduction } \\
\text { Internal rotation } \\
\text { External rotation } \\
\text { External rotation }\end{array}$} \\
\hline \multirow[t]{2}{*}{ Definition } & Rotator cuff tendinitis & \multicolumn{2}{|l|}{ Rotator cuff tear } \\
\hline & Inflammation in the tendon & \multicolumn{2}{|c|}{ Injury in the tendon can be partial or complete tear } \\
\hline Risk factors & \multicolumn{3}{|c|}{$\begin{array}{l}\text { Excessive overhead activity, repetitive stressful movement, obesity, anatomic variants, scapular } \\
\text { instability, dyskinesia or hypermobility, old age, Chronic diseases (such as diabetes and } \\
\text { hyperlipidemia), and Lifting heavy objects [19]. Acute tear can also occur with a fall or forceful } \\
\text { injury. }\end{array}$} \\
\hline Symptoms & \multicolumn{3}{|c|}{$\begin{array}{l}\text { - Shoulder pain increasing with overhead activity } \\
\text { - Shoulder pain could be laterally or posteriorly. It depends on the muscle involved } \\
\text { - Limited shoulder movement particularly active ROM. } \\
\text { - In the case of rotator cuff tear, muscle weakness is more pronounced, and patients can be } \\
\text { asymptomatic. }\end{array}$} \\
\hline Signs & \multicolumn{3}{|c|}{ See (Chap. 2) } \\
\hline Special tests & \multicolumn{3}{|l|}{ See (Chap. 2) } \\
\hline
\end{tabular}


Table 22.4 (continued)

\begin{tabular}{|c|c|}
\hline Investigations & $\begin{array}{l}\text { Radiology: X-rays for tendon calcifications or bone deformation. } \\
\text { US high sensitivity and/or MRI to confirm diagnosis, asses rotator cuff tear and degeneration. }\end{array}$ \\
\hline Treatment & $\begin{array}{l}\text { Acutely-if there is significant tear refer the patient to orthopedic surgery. } \\
\text { In partial tear or tendinitis consider conservative therapy: } \\
\text { - Avoid aggravating activity. } \\
\text { - Apply ice over tendon for } 15 \text { mins } 4-6 \text { times daily. } \\
\text { - NSAIDs. Local glucocorticoid inject with lidocaine may be considered. } \\
\text { - Physiotherapy: Range of motion stretching and strengthening exercises. } \\
\text { Subacute treatment-If no improvement is achieved within two to three months: } \\
\text { - Glucocorticoids-subacromial glucocorticoid injection is a common treatment to controlling } \\
\text { the symptoms [20]. }\end{array}$ \\
\hline
\end{tabular}

Table 22.5 History, examination, diagnosis, and treatment of enthesitis

\begin{tabular}{|c|c|}
\hline Sites & $\begin{array}{l}\text { The common sites for enthesitis are in planter fascia at calcaneus and Achilles tendon in the heel. } \\
\text { However, there is a scoring system to measure the extent of enthesitis in different body sites }\end{array}$ \\
\hline Causes & $\begin{array}{l}\text { Ankylosing spondylitis, reactive arthritis, psoriatic arthritis, inflammatory bowel disease (IBD), } \\
\text { celiac disease, Whipple disease, acne-associated arthritis, fracture, trauma, and idiopathic } \\
\text { secondary usually to repetitive trauma or mechanical misalignment or over weight } \\
\text { History suggestive of SpA (see Chap. 1): Red eyes, pain with eyes movement, oral or genital ulcer, } \\
\text { genital discharge, back pain or other joint pain, diarrhea or bloody diarrhea resent gastroenteritis, } \\
\text { history of psoriasis, or family history of psoriasis }\end{array}$ \\
\hline Symptoms & Pain that increases with activity and possibly swelling \\
\hline Signs & $\begin{array}{l}\text { - local tenderness increase with movement } \\
\text { - swelling } \\
\text { - warmth } \\
\text { - decrease active ROM and stiffness } \\
\text { - other sites: Iliac crest, greater trochanter, medial and lateral epicondyles in elbow, tibial } \\
\text { tuberosities, plantus, costochondral junction, and humeral tuberosities } \\
\text { - Most enthesitis in SpA is not detected at clinical examination }\end{array}$ \\
\hline Investigations & $\begin{array}{l}\text { Special test: HLA B } 27 \\
\text { X-ray: Nonspecific finding: like intra-tendon focal edema, calcific deposit spars, soft tissue } \\
\text { swelling, and thickening } \\
\text { US: Better than clinical examination in the detection of enthesitis of the lower limbs in SpA. There } \\
\text { are specific radiographic definitions for enthesitis at different body sites }\end{array}$ \\
\hline Treatment & $\begin{array}{l}\text { Exercise program } \\
\text { Proper shoe wearing using custom made devices } \\
\text { Occupation-related measures } \\
\text { Local steroid injection in severe and resistant cases } \\
\text { In SpA: NSAIDs can be tried first, no clear evidence of efficacy for sulfasalazine [23] } \\
\text { and/or methotrexate [24] in enthesitis mainly presentation in SpA. However, several studies } \\
\text { showed efficacy of anti-TNF-alpha therapy and IL-17 antagonists in severe enthesitis [25] }\end{array}$ \\
\hline
\end{tabular}

\subsubsection{Enthesitis}

It is inflammation at the site of insertion of ligaments, tendons, fascia, and articular capsules into the bone. It might be associated with pain at free nerve ending. It is the hallmark of spondyloarthritis ( $\mathrm{SpA}$ ) particularly when paravertebral ligaments are involved causing spondylitis. Extensive search for a systemic spondyloarthritic disease (see Chap. 1) should be sought in patients presenting with common enthesitis like Achilles tendinitis and plantar fasciitis [21, 22]. However, most of these enthesitis disorders have no systemic correlation, and they are induced by regional pathophysiological mechanisms. Table 22.5 represents a review about enthesitis. Tables 22.6, 22.7 and 22.8 summarize common enthesitis encountered in clinical practice: Achilles tendinitis, epicondylitis, and plantar fasciitis (Table 22.6). 
Table 22.6 Achilles Tendonitis [21, 22]

\begin{tabular}{|c|c|}
\hline Anatomy & $\begin{array}{l}\text { It is the largest tendon in the body formed by the union of tendons of soleus and gastrogenemius } \\
\text { muscles to form Achilles tendon. It inserts posteriorly at the calcaneus }\end{array}$ \\
\hline Muscles action & Plantar flexion \\
\hline Epidemiology & $\begin{array}{l}\text { - patients are usually } 30-40 \text { years of age } \\
\text { - males are equally affected like females } \\
\text { - rupture Achilles tendon is five times more common in males }\end{array}$ \\
\hline Risk factors & $\begin{array}{l}\text { Excessive supination, increase intensity of training program and increasing time in training } \\
\text { (basketball and football players), repetitive stress, obesity, male gender, previous history, } \\
\text { mechanical factors: Pes planus and pes cavus deformities, over pronation of foot, and drugs- } \\
\text { Fluoroquinolone or local glucocorticoid use }\end{array}$ \\
\hline Symptoms & $\begin{array}{l}\text { - pain with activity relieved after rest } \\
\text { - pain } 2-6 \mathrm{~cm} \text { above insertion of the tendon, swelling, and possibly redness } \\
\text { - in rupture Achilles tendon patient feels struck violently in the back of ankle or hears loud } \\
\text { popping sound with severe pain } \\
\text { - absence of pain dose not rule out Achilles tendon rupture }\end{array}$ \\
\hline Signs & $\begin{array}{l}\text { - gait and excessive foot supination. This is common with genu varaus deformity in the knee } \\
\text { - examine the patient in prone position with feet hanging off at the end of the bed } \\
\text { - inspect for bruising, swelling, and foot misalignment } \\
\text { - palpation: Hotness, thick tendon or defect, edema, hematoma, tenderness } \\
2-6 \mathrm{~cm} \text { above calcaneus and compare it with the other side } \\
\text { - palpate the tendon in while in dorsiflexion of the ankle, plantar flexion, and } \\
\text { Neutral position } \\
\text { - assess retrocalcaneal bursitis as one of the differential diagnosis for heel pain } \\
\text { - crepitus in chronic tendinitis } \\
\text { - assess for peripheral vascular disease (pulse, capillary refill, hair loss, and edema) } \\
\text { Notes: } \\
\text { The retrocalcaneal bursitis causes pain, fullness, or swelling proximal and anterior to the } \\
\text { insertion of Achilles tendon in to the calcaneus } \\
\text { The posterior tibial tendinitis causes pain in medial side of the ankle }\end{array}$ \\
\hline Special tests & $\begin{array}{l}\text { - calf squeeze or (Thompson test): Sensitivity of } 96 \% \text { and specificity of } 93 \% \text { [21] (see } \\
\text { Chap. 2) } \\
\text { - Matles test: Sensitivity of } 88 \% \text { and specificity of } 85 \% \text { : [21] } \\
\text { The patient lies prone with knees flexed to } 90^{\circ} \text {. Observe whether the affected foot is } \\
\text { dorsiflexed or neutral (both are abnormal) compared with the uninjured side, where the foot } \\
\text { should appear plantar-flexed }\end{array}$ \\
\hline Investigations & $\begin{array}{l}\text { Radiology: US and/or MRI to confirm diagnosis, monitor treatment response, and/or to assess } \\
\text { why the patient is not responding if another diagnosis is missing }\end{array}$ \\
\hline Treatment & $\begin{array}{l}\text { Avoid aggravating activity, support Achilles tendon with bandage, apply ice, NSAIDs can be } \\
\text { used, avoid glucocorticoid at it is associated with high risk of tendon rupture [22]. Consider } \\
\text { corrections of mechanical defects by providing custom-made orthotics that provide arch support } \\
\text { Consider rehabilitation and occupational therapy programs with eccentric exercise for around } 12 \\
\text { weeks. Air heel brace cast can be used in severe cases } \\
\text { Superficial heat and cold compressors } \\
\text { Deep heat by (US and iontophoresis) } \\
\text { Surgery can be considered in refractory cases after } 3-6 \text { months if no improvement all measures } \\
\text { Acute tendon rupture: Apply ice, analgesic, rest the ankle, and consider immobilization trial in } \\
\text { few degrees of plantarflexion. Consider surgical referral for partial ruputure: there is still no } \\
\text { clear rule for surgical intervention }\end{array}$ \\
\hline
\end{tabular}




\subsubsection{Achilles Tendinitis}

See Table 22.6.

\subsubsection{Epicondylitis $[26,27]$}

See Table 22.7

\subsubsection{Fasciitis}

A fascia is a layer of fibrous connective tissue (collagen) below the skin that covers underlying tissues (muscles, blood vessels, and nerves). Fasciitis is the inflammation of the fascia that causes fibrosis and loss of elasticity. The most common types of fasciitis are

Table 22.7 Lateral and medial epicondylitis

\begin{tabular}{|c|c|c|}
\hline Types & $\begin{array}{l}\text { Lateral epicondylitis (tennis elbow): } \\
15 \text { times more common than medial epicondylitis } \\
\text { Females are equally affected like males }\end{array}$ & $\begin{array}{l}\text { Medial epicondyle (golfer } \\
\text { elbow): } \\
\text { Less common }\end{array}$ \\
\hline Definition & $\begin{array}{l}\text { It is inflammation at bony origin for wrist extensors muscles } \\
\text { (extensor carpi radialis brevis "inserted in posterior base of } \\
\text { third metacarpal" and extensor digitorum communis), due to } \\
\text { overuse. The elbow of the dominant arm is affected more }\end{array}$ & $\begin{array}{l}\text { It is inflammation at bony origin } \\
\text { for wrist flexors muscles (pronator } \\
\text { teres and flexor carpi radialis) }\end{array}$ \\
\hline $\begin{array}{l}\text { Muscles } \\
\text { action }\end{array}$ & Extensor and abductor of the hand at wrist joint & $\begin{array}{l}\text { Flexors of fingers and thumb. } \\
\text { Also, flexors and pronators of the } \\
\text { wrist }\end{array}$ \\
\hline Risk factors & $\begin{array}{l}\text { ge: Player } 30 \text { years or older, smoking, obese, } \\
\text { ennis ball player, Occupation: Computer user and repeat } \\
\text { novement for } 2 \text { h daily }[27,28]\end{array}$ & \\
\hline $\begin{array}{l}\text { Physical } \\
\text { exam }\end{array}$ & $\begin{array}{l}\text { - localize tenderness in lateral epicondyle } \\
\text { - pain on resisted wrist extension while elbow in flexion } \\
\text { - pain in resisted supination and hand shaking } \\
\text { - pain in resisted middle finger extension } \\
\text { - Normal ROM of the elbow except in severe cases } \\
\text { - few degrees of extension might be affected } \\
\text { - examine radial nerve } \\
\text { - in compression neuropathy the pain diffuses distally to } \\
\text { epicondyle and is associated with muscle weakness }\end{array}$ & $\begin{array}{l}\text { - Localized tenderness in medial } \\
\text { epicondyle } \\
\text { - Pain on resisted wrist flexion } \\
\text { while elbow in extension } \\
\text { - pain with resisted forearm } \\
\text { pronation } \\
\text { - examine ulnar nerve }\end{array}$ \\
\hline Investigation & \multicolumn{2}{|c|}{$\begin{array}{l}\text { It is a clinical diagnosis and investigations are usually not required } \\
\mathrm{X} \text {-rays if indicated to look for osteophytes and calcification in epicondyle }\end{array}$} \\
\hline Treatment & \multicolumn{2}{|c|}{$\begin{array}{l}\text { Phase 1: Symptom less than } 6 \text { weeks } \\
\text { - rest the joint and use splint } \\
\text { - physiotherapy (eccentric exercise) } \\
\text { - NSAID: There is limited evidence, oral NSAIDs helps to reduce pain and improve the function } \\
\text { in } 6 \text { weeks [27], and there is limited benefit of topical NSAIDs in acute epicondylitis [29] } \\
\text { Phase 2: If symptoms do not improve for } 6-12 \text { weeks } \\
\text { - repeat } 3 \text { views X-ray to identify other possible causes } \\
\text { - continue eccentric exercise } \\
\text { - local injection of corticosteroid. If no improvement, repeat in 2-4 weeks for total of } 2 \\
\text { Doses. Use of local corticosteroid injection in lateral epicondylitis improves many patient } \\
\text { Symptoms in } 6 \text { weeks but does not prevent recurrences and long-term outcome worseness } \\
\text { [30, 31] } \\
\text { Phase 3: If symptoms do not improve after } 12 \text { weeks } \\
\text { - do US and/or MRI } \\
\text { Alternate treatment option might be considered as platelet-rich plasma injections, autologous blood } \\
\text { injections, prolotherapy, extracorporeal shock wave therapy, and percutaneous needle tenotomy [32] } \\
\text { - surgery if more than } 6 \text { months with failed conservative therapy including corticosteroid } \\
\text { injection } \\
\text { - 1. debridement +_arthroscopic drain } \\
\text { - 2. open debridement } \\
\text { - 3. Pericutanous tenotomy }\end{array}$} \\
\hline
\end{tabular}


planter fasciitis, palmar fasciitis, and eosinophilic fasciitis (these types can be secondary to autoimmune rheumatological diseases and malignancies).

\subsubsection{Plantar Fasciitis}

See Table 22.8 .

\subsubsection{Palmar Fasciitis}

See Table 22.9.

\subsubsection{Eosinophilic Fasciitis}

See Table 22.10.

Table 22.8 Planter fasciitis anatomy, history, physical exam, investigation and treatment

\begin{tabular}{|c|c|}
\hline \multicolumn{2}{|l|}{ Planter fasciitis } \\
\hline Anatomy & $\begin{array}{l}\text { It is a thick white tissue with longitudinal fibers attach to medial process of calcaneal tuberosity } \\
\text { divide to five slips continuing forward to form fibrous of flexor sheathes on plantar aspect one for } \\
\text { each toe }\end{array}$ \\
\hline History & $\begin{array}{l}\text { Age } 40-60 \text { years old } \\
\text { Pain in planter region that worse when initiate walking during the first few steps in morning } \\
\text { Aggravating factors: prolong standing or jumping, flat foot, high arch foot, heel spurs, running, } \\
\text { excessive training during aerobic exercise and obesity }[33,34] \\
\text { Symptoms suggestive of SpA (see Chap. 1) [35] }\end{array}$ \\
\hline $\begin{array}{l}\text { Physical } \\
\text { examination }\end{array}$ & $\begin{array}{l}\text { - local tenderness } \\
\text { - limited ankle dorsiflexion } \\
\text { The examiner should dorsiflex the patient toes with one hand, then pull the plantar } \\
\text { Fascia tight, and then palpate with thumb or index finger of other hand, the fascia } \\
\text { From heel particularly the medial aspect where the plantar fascia originates to the } \\
\text { Forefoot: Tenderness can be elicited }\end{array}$ \\
\hline Investigations & $\begin{array}{l}\text { - HLA-B27 and CRP if SpA is suspected } \\
\text { - X-rays: Lateral and axial films to detect thickness, fat pad abnormality, heel spur } \\
\text { And to rule out other causes } \\
\text { - MRI in resistant cases [36] } \\
\text { - US: } 80 \% \text { sensitivity and } 88,5 \% \text { specificity to detect fascia thickening and edema [37] }\end{array}$ \\
\hline Treatment & $\begin{array}{l}\text { - } 80 \% \text { resolve spontaneously by } 12 \text { months } \\
\text { - decrease physical activity and consider stretching exercise } \\
\text { - arch support with custom made orthotics and avoid flat shoes } \\
\text { - ice massage } \\
\text { - NSAIDs can be tried for } 2-3 \text { weeks } \\
\text { - inject with local glucocorticoid and lidocaine in resistant cases } \\
\text { Mechanical defects should be corrected otherwise symptoms may recur } \\
\text { - botulinum toxin injection might be considered } \\
\text { - for resistant cases refer to surgery for cast and possible splint extracorporeal shock wave } \\
\text { therapy }\end{array}$ \\
\hline
\end{tabular}


Table 22.9 Palmar fasciitis: definition, risk factors, symptoms, physical exam, investigation and treatment

\begin{tabular}{|c|c|}
\hline \multicolumn{2}{|c|}{ Palmar fasciitis (palmar fibromatosis) } \\
\hline Definition & Inflammation of the palmar fascia which causes fibrosis \\
\hline Risk factors & $\begin{array}{l}\text { Malignancy most common as ovarian cancer but can also be associated with breast, lung, } \\
\text { pancreas, stomach, colon, and metastasis [38] }\end{array}$ \\
\hline Symptoms & $\begin{array}{l}\text { - Pain in palm with swelling: inability to close hands resulting in limitation of activity and } \\
\text { function } \\
\text { - joints pain } \\
\text { - vasomotor symptoms } \\
\text { - symptoms suggestive malignancy }\end{array}$ \\
\hline $\begin{array}{l}\text { Physical } \\
\text { examination }\end{array}$ & $\begin{array}{l}\text { - tenderness and swelling of bilateral palms with tight fascia and fibrosis (woody hands) } \\
\text { - symmetrical polyarthritis and flexion deformity of the fingers } \\
\text { - Nailfold capillary is normal }\end{array}$ \\
\hline Investigations & $\begin{array}{l}\text { - tissue biopsy shows extensive fibrosis with fibroblast and mononuclear cell infiltration } \\
\text { - screening for malignancy }\end{array}$ \\
\hline Treatment & $\begin{array}{l}\text { - treat underlying malignancy if patient has metastasis and has poor prognosis } \\
\text { - NSAIDs } \\
\text { - corticosteroid } \\
\text { - ganglion blockade }\end{array}$ \\
\hline
\end{tabular}

Table 22.10 Eosinophilic fasciitis definition, risk factors, symptoms, physical exam, investigation and treatment

Eosinophilic Fasciitis (Shulman's syndrome or diffuse fasciitis with eosinophilic)

\begin{tabular}{|c|c|}
\hline Definition & Inflammation of the fascia with eosinophils infiltration causes fibrosis in early stages \\
\hline Risk factors & Hematological malignancy leukemia, myelodysplasia, and aplastic anemia [39] \\
\hline Symptoms & $\begin{array}{l}\text { Stage 1: } \\
\text { - pitting edema bilaterally most involving both arms and legs with sparing fingers and toes } \\
\text { - proximal area more than distal in the extremities } \\
\text { - no Raynaud's phenomenon } \\
\text { Stage 2: } \\
\text { - sever induration of the skin and subcutaneous tissue with peau d's orange appearance } \\
\text { - Groove sign is an induration due to retraction of the subcutaneous tissue along the } \\
\text { superficial veins } \\
\text { - mild myositis with normal CK level } \\
\text { Stage3: } \\
\text { - Neuropathy like carpal tunnel syndrome } \\
\text { - flexion deformity of the digits } \\
\text { - muscle atrophy } \\
\text { - no sclerodactyly and normal nailfold capillary }\end{array}$ \\
\hline Investigations & $\begin{array}{l}\text { - } \text { CBC and peripheral blood film look for hematological malignancy } \\
\text { - peripheral eosinophilia in } 80 \% \text { of the cases and the degree of eosinophilia does not correlate } \\
\text { with disease activity } \\
\text { - elevated ESR and CRP } \\
\text { - aldolase can be elevated with normal CK } \\
\text { - presence of polyclonal hypergammagloblinemia } \\
\text { - tissue biopsy shows inflammation and fibrosis in all skin layers except the epidermis and } \\
\text { eosinophils infiltration can be seen in early stages } \\
\text { - MRI findings fascial thickening with enhancement }\end{array}$ \\
\hline Treatment & $\begin{array}{l}\text { - treat underlying causes } \\
\text { - some patients may experience spontaneous improvement as the disease can be self-limited } \\
\text { - complete remission can be seen after } 2 \text { years or more } \\
\text { - high dose of prednisolone } 20-60 \mathrm{mg} / \text { day } \\
\text { - in resistant cases use hydroxychloroquine and methotrexate }\end{array}$ \\
\hline $\begin{array}{l}\text { Poor prognostic } \\
\text { factors }\end{array}$ & $\begin{array}{l}\text { - young age at onset of the disease } \\
\text { - trunk involvement }\end{array}$ \\
\hline
\end{tabular}


Acknowledgments The authors would like to thank Dr. Waleed Hafiz for his assistance in the development of this chapter.

\section{References}

1. Dillon JP, Freedman I, Tan JS, et al. Endoscopic bursectomy for the treatment of septic pre-patellar bursitis: a case series. Arch Orthop Trauma Surg. 2012;132:921.

2. Higuchi T, Ogose A, Hotta T, et al. Clinical and imaging features of distended scapulothoracic bursitis: spontaneously regressed pseudotumoral lesion. J Comput Assist Tomogr. 2004;28:223.

3. Conduah AH, Baker CL 3rd, Baker CL Jr. Clinical management of scapulothoracic bursitis and the snapping scapula. Sports Health. 2010;2:147.

4. Lehtinen JT, Macy JC, Cassinelli E, Warner JJ. The painful scapulothoracic articulation: surgical management. Clin Orthop Relat Res. 2004;99

5. Valeriano-Marcet J, Carter JD, Vasey FB. Soft tissue disease. Rheum Dis Clin N Am. 2003;29:77.

6. Söderquist B, Hedström SA. Predisposing factors, bacteriology and antibiotic therapy in 35 cases of septic bursitis. Scand J Infect Dis. 1986;18:305.

7. Roschmann RA, Bell CL. Septic bursitis in immunocompromised patients. Am J Med. 1987;83:661.

8. Cea-Pereiro JC, Garcia-Meijide J, Mera-Varela A, Gomez-Reino JJ. A comparison between septic bursitis caused by staphylococcus aureus and those caused by other organisms. Clin Rheumatol. 2001;20:10.

9. Perez C, Huttner A, Assal M, et al. Infectious olecranon and patellar bursitis: short-course adjuvant antibiotic therapy is not a risk factor for recurrence in adult hospitalized patients. J Antimicrob Chemother. 2010;65:1008.

10. Rubayi S, Montgomerie JZ. Septic ischial bursitis in patients with spinal cord injury. Paraplegia. 1992;30:200.

11. Schumacher HR. Arthrocentesis, synovial fluid analysis, and synovial biopsy. In: Schumacher HR, editor. Primer on rheumatic diseases. 10th ed. Atlanta, GA: Arthritis Foundation; 1993. p. 67-72.

12. Enzenauer RJ, Pluss JL. Septic olecranon bursitis in patients with chronic obstructive pulmonary disease. Am J Med. 1996;100:479.

13. Mathew SD, Tully CC, Borra H, et al. Septic subacromial bursitis caused by mycobacterium kansasii in an immunocompromised host. Mil Med. 2012; 177:617.

14. Canoso JJ, Yood RA. Reaction of superficial bursae in response to specific disease stimuli. Arthritis Rheum. 1979;22:1361.

15. Coste N, Perceau G, Léone J, et al. Osteoarticular complications of erysipelas. J Am Acad Dermatol. 2004;50:203.

16. Lindgren PG, Willen R. Gastrocnemiosemimembranosus bursa and its relation to the knee joint. I. Anatomy and histology. Acta Radiol Diagn (stockh). 1977;18:497.

17. Levitin PM. Letter:diagnosis of baker's cyst. JAMA. 1976;236:253.

18. Acebes JC, Sanchez-Pernaute O, Diaz-Oca A, Herrero-Beaumont G. Ultrasonographic assessment of Baker's cysts after intra-articular corticosteroid injection in knee osteoarthritis. J Clin Ultrasound. 2006;34:113.

19. Mehta S, Gimbel JA, Soslowsky LJ. Etiologic and pathogenetic factors for rotator cuff tendinopathy. Clin Sports Med. 2003;22:791.

20. Buchbinder R, Green S, Youd JM. Corticosteroid injections for shoulder pain. Cochrane Database Syst Rev. 2003:CD004016.

21. Alfredson H, Lorentzon R. Chronic Achilles tendinosis: recommendations for treatment and prevention. Sports Med. 2000;29:135.

22. McLauchlan GJ, Handoll HH. Interventions for treating acute and chronic Achilles tendinitis. Cochrane Database Syst Rev. 2001:CD000232.

23. Song I-H, Hermann KG, Haibel H, Althoff CE, Listing J, Burmester GR, Krause A, Bohl-Bühler M, Freundlich B, Rudwaleit M, Sieper J. Effects of etanercept versus sulfasalazine in early axial spondyloarthritis on active inflammatory lesions as detected by whole-body MRI (ESTHER): a 48-week randomised controlled trial. Ann Rheum Dis. 2011;70(4):590-6.

24. Chen J, Liu C. Methotrexate for ankylosing spondylitis. Cochrane Database Syst Rev. 2004;(3): CD004524.

25. Dougados M, Combe B, Braun J, Landewé R, Sibilia J, Cantagrel A, Feydy A, van der Heijde D, Leblanc V, Logeart I. A randomised, multicentre, double-blind, placebo-controlled trial of etanercept in adults with refractory heel enthesitis in spondyloarthritis: the HEEL trial. Ann Rheum Dis. 2010;69(8):1430-5.

26. Nirschl RP. The etiology and treatment of tennis elbow. J Sports Med. 1974;2:308.

27. Gruchow HW, Pelletier D. An epidemiologic study of tennis elbow. Incidence, recurrence, and effectiveness of prevention strategies. Am J Sports Med. 1979;7:234.

28. Green S, Buchbinder R, Barnsley L, et al. Nonsteroidal anti-inflammatory drugs (NSAIDs) for treating lateral elbow pain in adults. Cochrane Database Syst Rev. 2002:CD003686.

29. Burnham R, Gregg R, Healy P, Steadward R. The effectiveness of topical diclofenac for lateral epicondylitis. Clin J Sport Med. 1998;8:78.

30. Tonks JH, Pai SK, Murali SR. Steroid injection therapy is the best conservative treatment for lateral epicondylitis: a prospective randomised controlled trial. Int J Clin Pract. 2007;61:240.

31. Olaussen M, Holmedal O, Lindbaek M, et al. Treating lateral epicondylitis with corticosteroid injections or non-electrotherapeutical physiotherapy: a systematic review. BMJ Open. 2013;3:e003564.

32. Peerbooms JC, et al. Positive effect of an autologous platelet concentrate in epicondylitis in double-blind 
randomized controlled trial: platelet-rich plasma versus corticosteroid injections with a 1-year follow-up. Am J Sports Med. 2010;38:255.

33. Placzek R, Drescher W, Deuretzbacher G, et al. Treatment of chronic radial epicondylitis with botulinum toxin A. A double-blind, placebo-controlled, randomized multicenter study. J Bone Joint Surg Am. 2007;89:255.

34. Warren BL, Jones CJ. Predicting plantar fasciitis in runners. Med Sci Sports Exerc. 1987;19:71.

35. Warren BL. Anatomical factors associated with predicting plantar fasciitis in long-distance runners. Med Sci Sports Exerc. 1984;16:60.
36. Harvey CK. Fibromyalgia. Part II. Prevalence in the podiatric patient population. J Am Podiatr Med Assoc. 1993;83:416.

37. Sabir N, Demirlenk S, Yagci B, et al. Clinical utility of sonography in diagnosing plantar fasciitis. J Ultrasound Med. 2005;24:1041.

38. Cox NH, Ramsay B, Dobson C, Comaish JS. Woody hands in a patient with pancreatic carcinoma: a variant of cancer-associated fasciitis-panniculitis syndrome. Br J Dermatol. 1996;135:995.

39. Hoffman R, Dainiak N, Sibrack L, et al. Antibodymediated aplastic anemia and diffuse fasciitis. N Engl J Med. 1979;300:718.

Open Access This chapter is licensed under the terms of the Creative Commons Attribution 4.0 International License (http://creativecommons.org/licenses/by/4.0/), which permits use, sharing, adaptation, distribution and reproduction in any medium or format, as long as you give appropriate credit to the original author(s) and the source, provide a link to the Creative Commons license and indicate if changes were made.

The images or other third party material in this chapter are included in the chapter's Creative Commons license, unless indicated otherwise in a credit line to the material. If material is not included in the chapter's Creative Commons license and your intended use is not permitted by statutory regulation or exceeds the permitted use, you will need to obtain permission directly from the copyright holder. 